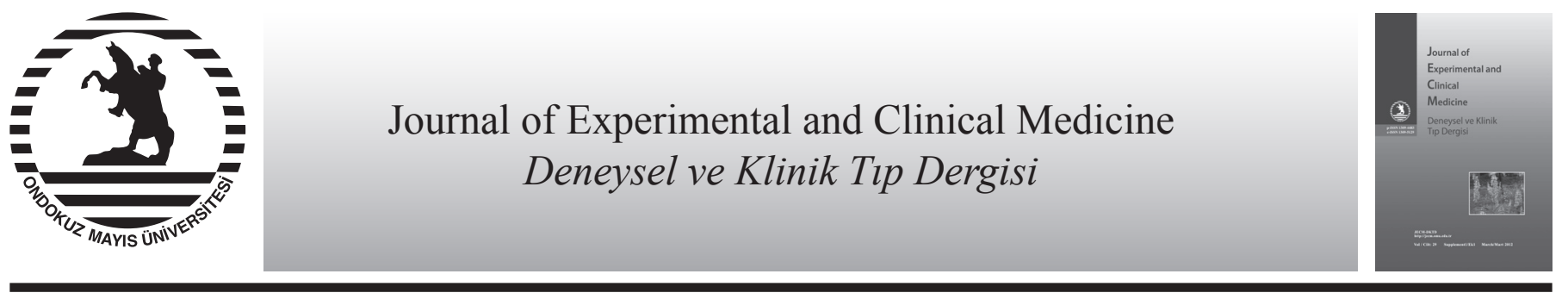

Derleme / Review

doi: $10.5835 /$ jecm.omu.29.s1.004

\title{
Tip 2 diabetes mellitusda tıbbi beslenme tedavisi
}

\section{Medical nutrition therapy in type 2 diabetes mellitus}

\author{
Güzin Tümer, Ramis Çolak*
}

Ondokuz Mayıs Üniversitesi, Tıp Fakültesi, Endokrinoloji ve Metabolizma Hastalıkları Bilim Dalı, Samsun, Türkiye

\begin{tabular}{|c|c|}
\hline МАKA & GÍLERİ \\
\hline Makal & \\
\hline Geliş & 13 / $01 / 2011$ \\
\hline Kabul & 15 / 02 / 2011 \\
\hline * Yazış & \\
\hline Ramis & \\
\hline Ondok & Üniversitesi \\
\hline Tip Fal & Idokrinoloji ve Metabolizma \\
\hline $\begin{array}{l}\text { Hastali } \\
\text { e-posta }\end{array}$ & $\begin{array}{l}\text { m Dalı, Samsun, Türkiye } \\
\text { olak@omu.edu.tr }\end{array}$ \\
\hline
\end{tabular}

\section{Anahtar Kelimeler:}

Diabetes mellitus

Diyet

Tibbi beslenme tedavisi

Metabolik kontrol

\section{Keywords:}

Diabetes

Diet

Medical Nutrition Therapy

Metabolic control

\section{ÖZET}

Tıbbi Beslenme Tedavisi (TBT) diyabetik hastaların tedavisinin temel taşlarından birisidir ve hastalığın seyri boyunca tedavinin bir parçası olmalıdır. Yeterli TBT uygulamadan, diğer tedavi yöntemleriyle metabolik kontrolün sağlanması güçtür. Bazı tip 2 diyabetli hastalarda sadece TBT uygulamakla kan şekeri düzeyleri ayarlanabilmektedir. TBT hastanın ihtiyaçları doğrultusunda bireysel olarak hazırlanmalıdır. Diyabetli bireye beslenme programının düzenlenmesi ve beslenme eğitiminin yapılması gerekir. TBT'nin başarıya ulaşması için, hastanın beslenme alışkanlıkları ve sosyo-ekonomik durumu dikkate alınarak uygun beslenme planı hazırlanmalıdır.

J. Exp. Clin. Med., 2012; 29:S12-S15

\begin{abstract}
Medical Nutrition Therapy (MNT) is one of the cornerstones of treatment of diabetic patients and should be part of the treatment during the course of the disease. Without adequate application of MNT it is difficult to ensure metabolic control with other treatment methods. Adequate application of TBT, other treatment methods, metabolic control is difficult to ensure. Blood sugar levels of some patients with type 2 diabetes can be adjusted only by implementing the MNT. MNT should be prepared according to individual needs of patient. Regulation of nutrition and nutrition education program have to be done for the diabetic patients. For the success of MNT, appropriate diet plan should be prepared taking into account the patient's eating habits and the socio-economic status.

J. Exp. Clin. Med., 2012; 29:S12-S15
\end{abstract}

Diabetes mellitus (DM) giderek artan sıklığı, kontrolsüz kaldığında mortalite ve mobiditeyi artırıcı komplikasyonlarının olmas1 ve böylelikle hem bireye, hem de topluma ekonomik yük getirmesi nedeniyle önemli bir hastalıktır. Ciddi sağlık harcamalarına neden olan komplikasyonlarının önlenmesi ya da geciktirilmesi ise ideal tedavi ile sağlanabilir. İdeal tedavide, iyi glisemik kontrolün sağlanması ve diyabete eşlik eden diğer metabolik durumların düzeltilmesi amaçlanır. Çünkü iyi glisemik kontrol ile akut/kronik diabetik komplikasyonların önlenebildiği ya da geciktirilebildiği gösterilmiştir (Dinçağ, 2008).

Son 20-25 y1ldan bu yana diyabet diyetinin kavram ve içeriğinde çarpıcı değişiklikler olmuştur. Amerikan Diyabet Cemiyetinin daha önce yayınladığ diyabet diyeti ve diyabetteki beslenme prensip ve önerileri, beslenme tedavisindeki anlayış ve terminolojiyi değiştirmiştir. Terminoloji için tıbbi beslenme tedavisi deyimi, diyet kelimesinin yerini almış ve içerik açısından da tıbbi beslenme tedavisinde (TBT) düzenlemeler yapılmıştır (ADA, 2007).

Tibbi beslenme tedavisi ile yaşam döngüsünün değişik dönemlerinde tip 1 ve tip 2 diyabetli yetişkin, gebe, emziren kadın ve yaşlı erişkinlerin enerji ve besin öğesi gereksiniminin karşılanması planlanır (Özer, 2009).

Tıbbi beslenme tedavisinin hedefleri

1) Optimal metabolik sonuçları sağlamak ve sürdürmek;

*Kan glukoz düzeyini normal ya da normale yakın sınırlarda tutmak,

*Makrovasküler komplikasyon riskini azaltacak lipid ve lipoprotein profili oluşturmak

*Vasküler hastalık riskini azaltacak kan basıncı düzeyini sağlamak, korumak.

2) Diyabetin kronik komplikasyonlarını önlemek ve tedavi etmek; 
Obezite, dislipidemi, kardiyovasküler hastalık, hipertansiyon ve nefropatinin önlenmesi ve tedavisi için uygun beslenme ve yaşam tarzı değişikliklerini modifiye etmek.

3) Sağlıklı beslenme ve fiziksel aktivite ile sağlığın iyileştirilmesi, davranış değişikliğinin oluşturulması.

4) Bireysel ve kültürel tercihleri ve yaşam tarzını dikkate alarak bireysel beslenme gereksinimlerini sağlamaktır.

TBT, diyabetin önlenmesinde, mevcut olan diyabetin tedavisinde ve diyabetle ilişkili komplikasyon gelişiminin önlenmesinde ve tedavisinde etkilidir. Ayrıca diyabette kendi kendine yönetim eğitiminin de önemli bir bölümünü oluşturur. Genel popülasyon için uygun olan sağlıklı yaşam tarzına yönelik beslenme önerileri yetişkin diyabetliler için uygundur. Yetişkin diyabetlinin metabolik durumu ve besin tercihi göz önüne alınarak, bireye özgü verilen beslenme tedavisi ile tip 2 diyabetlilerde HbA1C düzeylerinde \%1-2 oranında azalma sağlanmıştır (Diabetes Group, 2002).

TBT uygulaması birbirini izleyen dört aşamadan oluşmaktadir.

1-Metabolik ve yaşam tarzı parametrelerini değerlendirme

a. Klinik veri, boy, ağırlık, beden kitle indeksi (BKİ), bel çevresi ölçümü

b. Beslenme hikayesi; besin tüketimi, mevcut beslenme tedavisi, alkol tüketimi, besin hazırlama-pişirme teknikleri takibi

c. Fiziksel aktivite durumu, enerji tüketimi, psikososyal ve ekonomik durum, yaşam koşulları, gelir düzeyi, eğitim düzeyi, stres düzeyi, aile desteği belirlenmesi

2- Hedef saptama; uygun biyokimyasal değerler, vücut ağırlığı kontrolü, uygun egzersiz tipi ve süresi, ögün düzeni oluşturma

3- Bu hedeflerin sağlanmasına yönelik öneriler ve eğitim; bireysel eğitim, grup eğitimi

4- Klinik sonuçları değerlendirme (3-6 ay, 1 yıl aralıklarla); ağırlık, BKİ, açlık kan şekeri, HbA1C, serum kolestrol değerleri, kan basıncı, besin tüketim değerlendirmesi (Bozkurt, 2008).

Günümüzde sedanter yaşamın etkisiyle obezite sıklığı ve bu duruma bağlı olarak diyabet görülme oranı da artmıştır. Tip 2 diyabetli olguların yaklaşık \%85-90'1 normalden fazla kilolu ya da obezdir. Aslında, yağ dokusu büyük bir endokrin organdır. Adiponektin, rezistin, visfatin, leptin ve TNF alfa gibi insülin direncinde önemli role sahip olan adipostokinleri salgılar ve obez tip 2 diyabetlilerde, adipostokinler olumsuz etkiye sahiptir. Yalnız erişkinlerde değil aynı zamanda çocuk ve adölesanlarda da insülin direncinin egemen olduğu DM'nın gelişme sıklığını arttırır. Bu nedenle obez diyabetik olgularda tedavinin amaçlarından biri hastaların beden ağırlıklarının azaltılması ve bunun korunmasıdır. Amaca yönelik olarak obez tip 2 diyabetli olgularda TBT ve fiziksel aktivite gibi yaşam tarzı değişikliklerinin oluşturulması tedavinin başarıya ulaşmasında büyük etkiye sahiptir (Yılmaz, 2009).

\section{TBT'de enerji ve fiziksel aktivite}

Diyabet ile ilişkili risklerin azaltılmasında vücut ağırlığının yönetimi önemlidir. Vücut ağırlığı yönetimi kilo kaybının sağlanması ve tekrar kilo alımının önlenmesini kapsar. Obez bireylerde bireyin diyete uyumunun sağlanması ve hılı ağırlık kaybından korunması için alınan enerjide orta düzeyde kalori kısıtlaması, beslenme öyküsü ile hesaplanandan 250-500 kkal eksiltme yapılması önerilir (Bozkurt, 2008).

Kilo kaybının sağlanmasında, gerekli olan kalori miktarındaki eksiltme ile haftada 400-800 gram kilo kaybı sağlayabilmek, oluşacak komplikasyon riskini düşürmede etkilidir. Örneğin insülin direnci gelişmiş tip 2 diyabetlilerde orta derecede kilo kaybının insülin direncini iyileştirdiği gösterilmiştir. Bireysel ve grup eğitimi, sık aralıklarla izlem, yaşam tarzı değişikliklerini (enerji ve yağ tüketiminin azaltılması ve fiziksel aktivitenin artırılmasını) hedefleyen yapılandırılmış program bütünlüğünün; başlangıç vücut ağırlığına kıyasla \%5-7 oranında kilo kaybı sağladığı bildirilmiştir. Bu nedenle tip 2 diyabetlilere verilen TBT ile öncelikli hedef, enerji al1mının azaltılması ve fiziksel aktiviteyi artırarak enerji tüketiminin artırılmasını diğer bir ifade ile negatif enerji dengesini oluşturacak yaşam tarzı değişikliklerini sağlamak olmalıdır (Hainer ve Toplak, 2008).

Fiziksel aktivitedeki artış tip 2 diyabetlilerde glisemiyi iyileştirebilir, insüline direnci azaltabilir ve kardiyovasküler risk faktörlerinde azalma sağlayabilir. Fiziksel aktivitenin tüm bu olumlu etkileri kilo kaybının sağlanmasından bağımsızdır. Haftada üç gün en az 150 dakika orta yoğunlukta fiziksel aktivite (tercihen yürüyüş) yapılması ve fiziksel aktivite yapmaksızın geçen günlerin üst üste 2 günden fazla olmaması önerilir (Diabetes Group, 2002).

\section{TBT'de karbonhidrat ve posa}

Diyabette karbonhidratlar neden önemlidir; diyet karbonhidratları postprandiyal glukozun en önemli etkenidir. Özellikle diyet bileşenindeki karbonhidratların türü ve miktarı kan glukozunu büyük ölçüde etkilemektedir. Karbonhidratlar, polimerizasyon düzeylerine göre sınıflandırılmakta; başlıca şekerler, oligosakkaritler ve polisakkaritler olmak üzere 3 gruba ayrılmaktadırlar. Besinlerin glisemik yanıtını etkileyen çeşitli faktörler vardır. Bunlar; karbonhidrat miktarı, şekerin türü (glukoz, fruktoz, sükroz, laktoz), nisaştanın türü (amiloz, amilopektin, dirençli nişasta), besinlerin pişirilmesi ve işlenmesi, yağlar, pektinler, fitatlar, taninler gibi diğer bileşenler, nişasta-protein ve nişasta-yağ kombinasyonlarıdır. Açlık veya öğün öncesi glukoz konsantrasyonu, uzamış öğün etkisi, glukoz intoleransının şiddeti glisemik yanıtı etkileyen faktörler arasında yer alır (Bozkurt, 2008).

Sükroz (çay şekeri): Tip 2 diyabetli bireylerde karbonhidrat miktarı sabit olduğunda nişasta ve sükrozun postprandiyal glukoz düzeyleri, insülin yanıtları ve plazma lipitlerine etkisi benzerdir. Ögünde sükroz alınacaksa, diğer karbonhidrat kaynağı ile yer değiştirmesi veya eklenecekse insülin dozu ayarlanması önerilmektedir. Sükroz alımının toplam enerjinin \%10’un altında olmasına dikkat edilmelidir.

Fruktoz (meyve şekeri): Yavaş emildiği için postprandiyal glukoz ve insülin yanıtı düşüktür. Diyabetik bireylerde \%15-20 fruktoz tüketimi, açlık total kolestrol ve LDL kolestrol düzeylerini artırmaktadır. Bu durum özellikle dislipidemili diabetikler için önem taşımaktadır. Fruktoz alımının enerjinin \%15-20'sini aşmaması önerilmektedir. Sükroz kadar enerji içerdiği için öğün planında enerji kaynağı olarak düşünülmelidir. Tatlandırıcı olarak fruktoz kullanımının kısıtlanması, fruktozun doğal olarak bulunduğu besinlerin (sebze ve meyve gibi) kısıtlanmaması önerilmektedir.

Posa: Yüksek posalı diyetin insülin ve kan glukozu üzerine yararlı etkileri olduğu çalışmalarla gösterilmiştir. Çözünür posa olan guar-pektin suplemanı glukoz kontrolünü iyileşti- 
rirken, buğday kepeği ve selüloz gibi çözünmez posa önemli bir değişiklik oluşturmamaktadır. $\beta$-glukogan, karbonhidrat ve lipitlerin sindirim-emilimini yavaşlattığı saptanmıştır. Posanın, glukoz kontrolü üzerindeki etkinliği;

a) Dolaşımdaki monositler üzerinde insülin reseptör say1sinin artmasi,

b) Postprandiyal glisemik dolaşımı azaltması,

c) Direk olarak hepatik glikoz metabolizmasını etkilemesi şeklinde sıralanabilir.

Diyet posası: Serum kolestrol seviyesini kolestramin ve diğer iyonların değişimi aracılığı ile safra asit kaybını arttırarak azaltır. Yüksek karbonhidrat içeren diyetlerin alınması ile serum açlık trigliserit konsantrasyonlarındaki normal olarak gözlenen artış diyet posasının artırılması ve yağın kısıtlanmas1 ile kontrol altına alınabilmektedir. Genelde çözünür posa kan lipitlerini ve postprandiyal kan glukoz eğrisini çözünmez posaya göre daha etkin bir şekilde düşürmektedir. Ayrıca, posadan zengin besinlerin rafine olanlara göre daha düşük enerji yoğunlukları vardır ve midede hacim oluşturarak doygunluğu arttırırlar. Böylece düşük enerjili diyetlerin kullanılabilirliliğini arttırırlar. Diyabetik hastalar için 20-35 g/gün diyet posas1 önerilmektedir. Posa kaynağı olarak: her gün sebze-meyve, kepek (yulaf, buğday) veya kepeği ayrılmamış tam taneli tahıl ürünleri, kuru baklagiller önerilir. Diyetin karbonhidrat içeriği hedeflenen kan glukoz ve lipit düzeylerine göre bireysel olarak enerjinin \%55-60'nı sağlayacak şekilde olması önerilmektedir (FAO/WHO, 1997).

Glisemik kaliteyi gösteren glisemik indeks ile glisemik kalite ve kantiteyi gösteren glisemik yük, diyet karbonhidratlarının değerlendirilmesinde kullanılan yöntemlerdir. Diyabetli bireylerde tokluk durumunda olduğu gibi açlık durumunda da kan glukoz düzeyi yükselebilmektedir. Bu anormal metabolik yanıt, yetersiz insülin direnci veya her ikisinin birlikte olmasından kaynaklanabilmektedir. Karbonhidrat tüketmemek kan glukoz düzeyini normal düzeye getirmemektedir. Diyabetin tedavisinde düşük karbonhidratlı diyetler önerilmemektedir. Diyet karbonhidratları enerjinin, suda çözünür vitaminlerin, minerallerin ve posanın en önemli kaynağını oluşturmaktadır. Beyin ve sinir sistemi için tek enerji kaynağı glukoz olduğundan yetişkinler için diyetin total karbonhidrat içeriği 130 g/gün'ün altında olması önerilmemektedir. Glisemik kontrolün başarılmasında karbonhidrat tüketiminin izlenmesi büyük önem taşımaktadır (Vessby, 1994).

\section{TBT'de protein}

Protein, enerji korunması için gereklidir. Diyabetli bireylerin protein alımında genel popülasyondan daha yüksek veya daha düşük protein alımını destekleyen veriler yetersizdir. Tip 2 diyabetiklerde orta düzeyde hipergliseminin protein döngüsünü arttırarak protein gereksinimini arttırabileceği ileri sürülmektedir. Proteinler insülin sekresyonunu stimüle ederler ve bu durum tip 2 diyabetiklerde daha belirgindir. İnsülin salımına etki eden güçlü aminoasitler; arginin, lizin, lösin, fenilalanindir. Ağıdan alınan amino asitler, intravenöz alınana göre daha fazla insülin yanıtı oluşturur. Proteinlerin insülin yanıtını arttırmasından dolayı akut hipoglisemi tedavisinde veya gece hipoglisemisini önlemek amacı ile tüketilmesi önerilmez. Protein alımı için öneri 0,8-1,0 g/kg/gündür. Kronik böbrek yetmezliğinin erken evrelerinde aynı düzey öneri devam ederken ilerleyen dönemde tüketim düzeyinin $0,8 \mathrm{~g} / \mathrm{kg} / \mathrm{gün}$ 'e çekilmesi böbrek fonksiyonlarında iyileşme sağlayabilmektedir (Bozkurt, 2008).

\section{TBT'de yağlar}

Diyetin yağ türü ve miktarı metabolik kontrol ve komplikasyonların gelişimi açısından büyük önem taşımaktadır. Tekli doymamış yağlardan zengin diyetin insülin direnci üzerine olumlu etkisi vardır. Çoklu doymamış yağlardan zengin diyetin, doymuş yağlardan zengin diyet ile kıyaslandığında total kolestrol ve LDL kolestrolünü düşürdüğü gösterilmiştir. Diyabette günlük yağ alımı, enerjinin \%30‘unu aşmaması önerilmektedir.

Birçok tip 2 diyabetlide hipertansiyon ve dislipidemi de olduğundan, diyabet tedavisinde doymuş yağ alımı toplam kalorinin \%7'sinden az olacak şekilde sinırlandırılmalıdır. Trans yağ ve çoklu doymamış yağ alımı \%10' un altında olmalıdır. Diyabetli bireylerde kolesterol alımı günde 200 mg' in altında olmalıdır (ADA, 2006).

\section{TBT'de vitamin ve mineraller}

Yapılan çalışmalarda diyabetiklerde lipid peroksidasyonunun artması sonucu metabolik kontrolün azaldığı gösterilmiş ve oksidatif stresin diyabetik komplikasyonların oluşumunda rol oynayabileceği ileri sürülmüştür. Diyabetik bireylerde yükselmiş lipid peroksidasyonuna bağlı olarak hücre membran akıcılığında değişiklikler oluşmakta bu da glukozun hücre içine taşınmasında azalmaya yol açmaktadır. E vitamininin, sağlıklı ve diyabetik bireylerde insülin yanıtını düzeltmesi antioksidan etkisine bağlanmaktadır. Önerilen ek E vitamini miktarı 100-200 mg/gün arasındadır. Askorbik asidin antioksidan özelliğinin olması nedeniyle E vitaminine benzer etki gösterebileceği düşünülmektedir. Deneysel olarak D vitamini yetersizliğinin insülin sekresyonunu azalttığı gösterilmiştir. Diyabetiklerde de D vitamini yetersizliği riskinin yüksek olabileceği düşünülmektedir. B6 vitamini ilavesinin diyabetik polinöropati tedavisinin etkinliğini arttırdığı gösterilmiştir (Bozkurt, 2008).

Magnezyum, insülin direnci ve karbonhidrat intoleransında rol oynar. Diyabetiklerde hipomagnezeminin kalp-damar komplikasyonlarını ve retinopatinin gelişimini arttırdığı ileri sürülmektedir. Hipomagnezemisi olanlara ilave yapılmalıdır.

Tip 2 diyabetiklerde 500 mcg krom eklenmesinin A1C, glukoz, insülin ve kolestrol düzeyine yararlı etkileri olduğu bildirilmiştir. Yetersizlik belirlenmedikçe ekleme önerilmemektedir.

Çinko, insülinin etki ve fizyolojisinde direk olarak katılan esansiyel bir mineraldir. Kan glukoz düzeyi ile ilişkisi olmamakla beraber ayak ülserinde hızlı iyileşme olduğu gösterilmiştir.

Diyabette kalsiyum metabolizması bozulduğundan ateroskleroz, hipertansiyon, gibi bozukluklar ortaya çıkmakta; bu olayında katarakt, renal hipertrofi ve nöropati gibi bozukluklara dolaylı olarak neden olabileceği belirtilmektedir.

Sodyum, barsak lümeninde glukoz ile aynı taşıyıcı üzerinden emilir. Sodyumla glukozun birlikte transportu kan şekerinin yükselmesine neden olduğu için hipertansiyon ve nefropati olabileceği düşünülerek diyetle alım sınırlandırılmaktadır. Diyabetikler için alım 3000 mg/gün olarak önerilmektedir. Hipertansiyonlu diyabetiklerde $2400 \mathrm{mg}$ /gün veya 6 gr tuz alımı önerilmektedir (Powers, 1996).

Eksiklik belirtileri bulunmaması koşulunda yetişkin diyabetlilere vitamin ve mineral takviyesi yapılması yönünde 
kanıtlar yetersizdir. Ancak enerji alımı azalmıș yaşlı erişkinlerde ve kısıtlı diyetlerde ( $<1200 \mathrm{kkal} /$ gün) günlük multivitamin takviyesi önerilebileceği bildirilmektedir (ADA, 2006).

Alkol, kan glukoz düzeyine etkisi sadece alınan miktara bağlı değil besin alımı ile ilişkisi de önemlidir. Diyabet iyi kontrollü olduğunda, besinlerle ve orta düzeyde alkol kullanımı kan glukoz düzeyini etkilemez. Yetişkin kadınlar için 1 ölçü, erkekler için 2 ölçü ( 1 ölçü=350 cc bira, 140 cc şarap veya 15 cc distile içki) dengeli yemek öğünü ile birlikte al1nabilir. Alkolden gelen kalori yağ değişimi olarak değerlendirilmelidir (Bozkurt, 2008).

Ögün sayısı ve dağılımı; diyabetik hastalarda besinlerin 2-3 öğünde tüketilmesi yerine gün içerisine dağıtılmasının yararlı olduğu gösterilmiştir. Özellikle bir miktar insülin üre- tebilen tip 2 diyabetlilerde, az ve sık öğünlerin endojen insülin üretimi için daha uygun olduğu saptanmıştır. Bireysel kan glukoz takibi ile ideal ögün aralığı ve miktarını belirlemek mümkündür

Tip 1 ve tip 2 diyabetlilere verilen TBT de tek bir beslenme modelinden söz edilemez. Her diyabetli bireyin tıbbi tedavisi farklı olduğu gibi TBT' de farklıdır. Bir diyabetli için uygun ve sağlıklı olan bir öneri bir başkası için uygun olmayabilir. TBT'ye başlamadan önce birey ve ailesinin beslenme alışkınlıkları, diyabetle ilişkili bilgi, davranış ve inançları değerlendirilmelidir. Farklı disipliner (doktor, diyetisyen, hemşire, psikolog) yaklaşımlar ve uygulamalar birlikte yürütülmelidir (Özer, 1999).

\section{KAYNAKLAR}

American Diabetes Association, 2006. Recommendations and interventions for diabetes. Diabetes Care. $29,2140-2157$.

Bozkurt, N., 2008. Diabetes mellitus ve beslenme ilkeleri. Diyet el kitab1. 257-287.

Carbohydrates in human nutrition report of a joint FAO/WHO expert concultation, 1997. Roma-Italy.

Clinical practice recommendations, 2007. ADA standarts of medical care in diabetes. Diabetes Care. 30, S4-S41.

Diabetes Prevention Program Research Group, 2002. Reduction in the incidance of type 2 diabetes with lifestyle intervention or metformin. Eng. J. Med. 346, 393-403.

Dinçağ, N., 2008. Sürekli glukoz izleme sistemi-diabette kendi kendine izleme, IV. Uluslar arası beslenme ve dietetik kongresi özet kitabı, 144145.

Hainer, V., Toplak, H., 2008. Treatment modilities of obesity. What fits whom? Diabetes Care. 32, 269-277

Özer, E.,1999. Diabet Diyetisyenliği Diabette Beslenme Tedavisi, HÜ Beslenme ve Diyetetik Bölümü ve TDD yayını, İstanbul

Özer, E., 2009. Tip1 ve Tip 2 diabette beslenme ve egzersiz, 45. Ulusal Diabet Kongre Kitab1. 45.

Powers, A.M., 1996. Handbook of Diabetes Medical Nutrition Therapy, An Apsen Publication, Maryland.

Vessby, B., 1994. Dietary carbohydrates in diabetes. Am. J. Clin. Nutr. 59, 7425-7465.

Y1lmaz, M., 2009. Obezite ve diabetes mellitus, 45. Ulusal Diyabet Kongre Kitab1. 54. 